\title{
DIETARY PROTEIN LEVELS AFFECT THE NURSING PERFORMANCE AND SERUM BIOCHEMICAL PROFILE OF LACTATING MINK (Neovison vison)
}

\author{
Q. Jiang ${ }^{1}$ T. Zhang ${ }^{1}$ G. Li $^{1}$ H. Zhang ${ }^{1}$ X. Gao ${ }^{2}$ X. Xing ${ }^{1}$ F. Yang ${ }^{1}$ and X. Wu ${ }^{3, *}$ \\ ${ }^{1}$ Institute of Special Animal and Plant Sciences, State Key Lab for Molecular Biology of Special Economic Animals, \\ Chinese Academy of Agricultural Sciences, Changchun City, Jilin, China 132109; ${ }^{2}$ Feed Research Institute, Chinese \\ Academy of Agricultural Sciences, Beijing, China 100081; ${ }^{3}$ College of Animal Science, Anhui Science and \\ Technology University, 1501 Huangshan Avenue, Bengbu, 233100, Anhui, China. \\ *Corresponding author's e-mail: wuxuezhuang@126.com
}

\begin{abstract}
This study was aimed to evaluate effects of dietary protein levels on the nursing performance of lactating mink (Neovison vison). A total of 120 pregnant mink were randomly assigned to 4 dietary treatment groups with protein levels of 32\% (P32, control), 36\% (P36), 40\% (P40) and 44\% (P44) (dry matter basis, corresponding to 29\%, 32\%, 36\% and $39 \%$ of ME), and fed ad libitum for 8 weeks from late gestation to the end of lactation. Results showed that daily weight gain of kits increased linearly with the increasing dietary protein levels although the difference was not significant. Similar trend was noted for the survival rate of kits at weaning. Dams fed diets with higher protein levels showed less body weight loss during lactation. Improved metabolic status was demonstrated by the changed metabolic profiles as indicated blood urea nitrogen level $(\mathrm{P}<0.05)$, total protein $(\mathrm{P}<0.05)$, glutamate pyruvate transaminase activity and blood glucose content $(\mathrm{P}<0.05)$. In conclusion, we found that dietary protein intake significantly affects the nursing performance of female mink. We suggest that an estimated dietary protein level of $44 \%$ (39\% of ME) could be used as a guidance to achieve the optimal performance of lactating dams.
\end{abstract}

Key words: dietary protein; female mink; lactation; nursing performance.

https://doi.org/10.36899/JAPS.2020.4.0098

Published online April 25, 2020

\section{INTRODUCTION}

Mink (Neovison vison) are widely raised in fur industry and they have only one breeding season per year. In the northern hemisphere, mink mate during the month of March, which lasts for approximately 20-25 days both in farm and in the wild. After an average of 51 daypregnancy parturition occurs, which is followed by lactation of 45-60 d (Hammer et al. 2017; Kiik et al. 2017).

Lactation is one of the most challenging physiological stages of mink's life cycle. As an obligate carnivore, mink require for diets with high in protein content. In particular, protein deficiency may significantly undermine the reproductive performance of mink. It is known that nutritional restriction during fetal development leads to permanent damage to physiology and metabolism of animals in adult life (Mcmillen and Robinson 2005). The negative effect of protein malnutrition was reported by and Vesterdorf et al. (2012) in mink dams of late gestation and lactation. Although protein requirement during lactation is high, excess intake can also lead to obesity, which can deleteriously impact mink productivity (Korhonen and Niemelä 1998). Studies have shown that increasing dietary protein intake results in increased metabolic rate and protein oxidation rate, leading to elevated oxidative stress (Fink and Børsting
2002; Rouvinen-Watt 2003). Such metabolic disorder often leads to the development of nursing sickness, which is responsible for most of the mortalities in lactating mink dams (Clausen et al. 1992). However, current recommendations of dietary protein level for the lactating mink are inadequate, and systematical evaluation of dietary protein requirement of female mink in lactation has been largely neglected (Skrede 1978; Glem-Hansen 1979; NRC 1982; Fink et al. 2002; Hynes and RouvinenWatt 2007). Thus, with the purpose for better estimating the protein requirement of lactating mink, this study was carried out to investigate effects of dietary protein levels on the nursing performance of lactating mink by measuring growth rate of the offspring, change of the dam's body weight and serum biochemical and metabolic parameters.

\section{MATERIALS AND METHODS}

Animals and management: The experiment was carried out at the Fur Animal Breeding Base of Institute of Special Animal and Plant Science, Chinese Academy of Agricultural Sciences $\left(44.02^{\circ} \mathrm{N}, 126.15^{\circ} \mathrm{E}\right)$ in the northeast of China, from March 2012 to May 2012, with the experimental protocol being reviewed and approved by the Animal Care Committee of the Institute. All procedures followed the Laws, Regulations, and 
Guidelines for Animal Research in China (Ogden et al. 2016) and were abided by the Welfare of Animals Kept for Fur Production of European Commission. 120 standard black genotype female mink (Neovison vison) of two-year-old were housed and managed as previously described (Jiang et al. 2015). The experimental period started from 14 day before parturition (March 2012) and end at weaning (May 2012). All animals were weighed prior to experiment and randomly distributed to four experimental groups employing the completely randomized design (CRD), and subjected to diets with protein levels of 32\% (P32, control group), 36\% (P36), $40 \%(\mathrm{P} 40)$ and $44 \%(\mathrm{P} 44)$, corresponding to an average of $320,360,400$ and $440 \mathrm{~g}$ protein $/ \mathrm{kg}$ dry matter (DM), respectively. Dietary carbohydrates (in the experiment from 413,8 to $246,7 \mathrm{~g} / \mathrm{kg}$ DM) were adopted to compensate the reduced protein levels (from 317.9 to $453 \mathrm{~g} / \mathrm{kg} \mathrm{DM}$ ) from group P32 to P44. To achieve isocaloric diets among groups, content of ether extract (EE) (g/kg DM) remained constant (from 166,5 to 167,0 $\mathrm{g} / \mathrm{kg} \mathrm{DM}$ ). The ingredients and chemical composition of diets were listed in Table 1, and amino acid content in Table 2.

Blood sampling and measurement of metabolic parameters: After weaning (45 days after birth), blood samples from these dams were collected for the determination of serum biochemical and metabolic parameters. Serum was immediately isolated by centrifugation at $2,500 \mathrm{~g}$ at $4^{\circ} \mathrm{C}$ for $5 \mathrm{~min}$ and kept frozen at $-80 \mathrm{C}$ for the determination of biochemical indicators. The blood urea nitrogen level (BUN), total protein content (TP), glutamate pyruvate transaminase activity (GPT), and blood glucose content (GLU) were measured using Hitachi 7020 automatic biochemistry analyzer (Hitachi High Technologies, Inc., Ibaraki, Japan) following kits' manufactural instructions (Nanjing Jiancheng Biochemical Corporation, Nanjing, China).

Chemical analysis: Chemicals analysis and $\mathrm{ME}$ calculation were performed as previously described (Jiang et al. 2015). Amino acids in diets were estimated on amino acid analyzer (L-8900, HITACHI, Japan), as described by Ma et al. (2010).

Nursing performance evaluation: All animals were inspected twice daily. Weights of individual nursing females and kits were recorded at regular intervals using an electronic scale, on the day after delivery or birth (= day 1), at days $9,18,27,36$, and on the day before weaning (= day 45). The average number of live-born kits per dam was considered as litter size. Nursing performance of dams were determined by parameters/indexes including mated female mink, liveborn kids per mated female, kits per litter, kits weight and barren female mink (Tauson and Aldén 1984; Shaw et al. 1997; Korhonen et al. 2002).
Statistical analysis: Data were analyzed as previously described (Jiang et al. 2015). Briefly, the data were analyzed with one-way ANOVA according to CRD design using SAS (version 8.2, SAS Institute, Inc., Cary, $\mathrm{NC}$, USA). Mean $\pm \mathrm{SD}$ are shown. $\mathrm{P}<0.05$ stands for statistical significance and $\mathrm{P}<0.01$ for highly statistical significance.

\section{RESULTS}

Kit growth dynamics and survival rate: No significant difference was observed regarding average litter size at birth and birth weight as compared to the control group (P32), indicating minimal effect of fetal life on the growth and mortality of the kits at birth. In contrast, dams fed the P44 exhibited much higher daily weight gain of kits and better growth performance throughout the lactation as compared to other groups, in particular to the control group. Similar tendency was also found on the survival rate of kits at weaning (Table 3, Fig.1).

Dams weight loss: After parturition, 8 female mink farrowing 5 to 9 kits were selected from each group for the measurement of growth dynamics of kits and body weight loss of the dams. Fig. 2 shows the live weight change of dams measured within 45 days after delivery and before weaning. While all animals showed decreased total body mass during the course of lactation, dams fed with high protein diet (P44) had significant less weight loss in comparison with dams fed with reduced protein $\operatorname{diet}(\mathrm{P} 36)(\mathrm{P}<0.05)$ (Table 4).

Serum parameters: To assess the potential effect of dietary protein levels on the health of dams, blood was collected at the end of lactation after overnight fasting for biomedical parameters measurement. Results indicated that BUN, TP and GLU increased steadily from control group to $\mathrm{P} 44$ with statistical significance (Table 5, $\mathrm{P}<0.05)$. GPT did not show differences among treatments, but notable elevation along with the increasing protein levels was observed, similar to results of other parameters.

\section{DISCUSSION}

Protein provision exerts significant effect on growth performance, nutrients digestibility, protein oxidation and fat metabolism of mink at various developmental stages (Matthiesen et al. 2012; Zhang et al. 2012; Zhang et al. 2013; Matthiesen et al. 2014). However, the impact of dietary protein on dams in lactation has been so far largely neglected in mink research. The present study focused on understanding the response of dams to different levels of dietary protein intake during lactation, with an eventual goal of improving nursing performance of the lactating mink. 
Table 1. Composition and nutrient levels of the experimental diets (air-dry basis, \%).

\begin{tabular}{|c|c|c|c|c|}
\hline Items & P32 & P36 & P40 & P44 \\
\hline \multicolumn{5}{|l|}{ Ingredients } \\
\hline Extruded corn & 33.82 & 29.45 & 24.70 & 19.02 \\
\hline Yellow croaker & 26.87 & 30.75 & 35.05 & 40.32 \\
\hline Poultry offal & 5.00 & 5.00 & 5.00 & 5.00 \\
\hline Boiled Eggs & 7.00 & 7.00 & 7.00 & 7.00 \\
\hline Lard & 20.81 & 21.30 & 21.75 & 22.16 \\
\hline Ox Liver & 5.00 & 5.00 & 5.00 & 5.00 \\
\hline Salt & 0.50 & 0.50 & 0.50 & 0.50 \\
\hline Vitamin/mineral premix ${ }^{1)}$ & 1.00 & 1.00 & 1.00 & 1.00 \\
\hline Total & 100.00 & 100.00 & 100.00 & 100.00 \\
\hline \multicolumn{5}{|l|}{ Nutrient levels ${ }^{2)}$} \\
\hline Ash, $\%$ of DM & 5.12 & 6.99 & 7.43 & 9.24 \\
\hline $\mathrm{CP}, \%$ of $\mathrm{DM}$ & 32.28 & 36.33 & 40.94 & 44.68 \\
\hline $\mathrm{EE}, \%$ of DM & 24.87 & 25.15 & 24.76 & 24.72 \\
\hline $\mathrm{Ca}, \%$ of $\mathrm{DM}$ & 2.86 & 2.89 & 2.85 & 2.84 \\
\hline $\mathrm{TP}, \%$ of $\mathrm{DM}$ & 1.92 & 1.89 & 1.96 & 1.83 \\
\hline $\mathrm{ME}(\mathrm{MJ} / \mathrm{kg})$ & 18.37 & 18.59 & 18.85 & 18.90 \\
\hline $\begin{array}{l}\mathrm{CP}: \text { Fat:CC ratio } \\
(\% \text { of } \mathrm{ME})\end{array}$ & $29: 54: 17$ & $32: 54: 14$ & $35: 53: 12$ & $39: 51: 10$ \\
\hline
\end{tabular}

Table 2. Amino acids content of experimental diets (\% DM).

\begin{tabular}{lllll}
\hline Items & P32 & P36 & P40 & P44 \\
\hline Aspartic acid & 2.02 & 2.19 & 2.39 & 2.63 \\
Threonine & 1.29 & 1.40 & 1.52 & 1.66 \\
Serine & 1.49 & 1.59 & 1.71 & 1.85 \\
Glutamic acid & 4.56 & 4.91 & 5.30 & 5.77 \\
Glycine & 1.75 & 1.92 & 2.10 & 2.32 \\
Alanine & 1.80 & 1.94 & 2.10 & 2.29 \\
Valine & 1.56 & 1.67 & 1.79 & 1.94 \\
Methionine & 1.04 & 1.12 & 1.21 & 1.32 \\
Isoleucine & 1.13 & 1.22 & 1.32 & 1.45 \\
Leucine & 2.31 & 2.46 & 2.62 & 1.83 \\
Tyrosine & 0.92 & 1.00 & 1.08 & 1.69 \\
Phenylalanine & 1.36 & 1.46 & 1.56 & 2.72 \\
Lysine & 2.05 & 2.24 & 2.46 & 0.77 \\
Histidine & 0.63 & 0.67 & 0.71 & 2.05 \\
Arginine & 1.59 & 1.72 & 1.87 & 0.91 \\
Proline & 0.76 & 0.80 & 0.85 & \\
\hline
\end{tabular}

Table 3. The effect of dietary protein levels on mink litter size and birth weight, daily weight gain and survival rate through weaning.

\begin{tabular}{lcccc}
\hline Items & P32 & P36 & P40 & P44 \\
\hline Litter size at birth & $6.63 \pm 1.69$ & $6.88 \pm 1.64$ & $5.88 \pm 1.46$ & $6.25 \pm 1.58$ \\
Birth weight (g) & $11.77 \pm 1.16$ & $11.36 \pm 1.77$ & $11.91 \pm 2.58$ & $10.76 \pm 1.50$ \\
Daily weight gain (g) & $7.00 \pm 0.29$ & $7.33 \pm 1.28$ & $7.28 \pm 1.37$ & $7.95 \pm 1.23$ \\
Weaning survival rate (\%) & $84.46 \pm 11.10$ & $85.84 \pm 12.60$ & $86.83 \pm 12.97$ & $87.50 \pm 14.77$ \\
\hline
\end{tabular}


Table 4. The effect of dietary protein levels on weaning weight loss of mink dams.

\begin{tabular}{lcccc}
\hline Items & P32 & P36 & P40 & P44 \\
\hline Weaning weight loss & $376.66 \pm 35.80^{\mathrm{ab}}$ & $443.78 \pm 39.71^{\mathrm{a}}$ & $381.56 \pm 37.61^{\mathrm{ab}}$ & $319.94 \pm 35.62^{\mathrm{b}}$ \\
Weaning weight loss rate $(\%)$ & $21.92 \pm 1.36^{\mathrm{ab}}$ & $24.54 \pm 1.90^{\mathrm{a}}$ & $20.85 \pm 1.27^{\mathrm{ab}}$ & $17.32 \pm 1.77^{\mathrm{b}}$ \\
\hline Notes: Means with different lowercase of superscripts were significantly different at $P<0.05$, and with different capital letters of \\
superscripts were highly significantly different at $P<0.01$.
\end{tabular}

Table 5. Effect of dietary protein levels on serum biochemical endpoints in female mink at the end of lactation.

\begin{tabular}{lcccc}
\hline Items & P32 & P36 & P40 & P44 \\
\hline BUN, mmol/L & $5.04 \pm 0.64^{\mathrm{b}}$ & $5.19 \pm 0.61^{\mathrm{b}}$ & $6.04 \pm 1.11^{\mathrm{ab}}$ & $7.18 \pm 1.154^{\mathrm{a}}$ \\
$\mathrm{TP}, \mathrm{g} / \mathrm{L}$ & $66.63 \pm 5.18^{\mathrm{Bc}}$ & $68.27 \pm 5.48^{\mathrm{Bbc}}$ & $74.91 \pm 5.89^{\mathrm{ABab}}$ & $80.39 \pm 6.61^{\mathrm{Aa}}$ \\
GPT, U/L & $117.13 \pm 11.06$ & $127.49 \pm 17.45$ & $135.88 \pm 18.61$ & $145.77 \pm 14.77$ \\
GLU, mmol/L & $4.75 \pm 0.38^{\mathrm{Bb}}$ & $5.03 \pm 0.50^{\mathrm{Bb}}$ & $5.75 \pm 0.24^{\mathrm{ABab}}$ & $6.53 \pm 0.51^{\mathrm{Aa}}$ \\
\hline
\end{tabular}

Notes: Means with different lowercase of superscripts were significantly different at $P<0.05$, and with different capital letters of superscripts were highly significantly different at $P<0.01$.

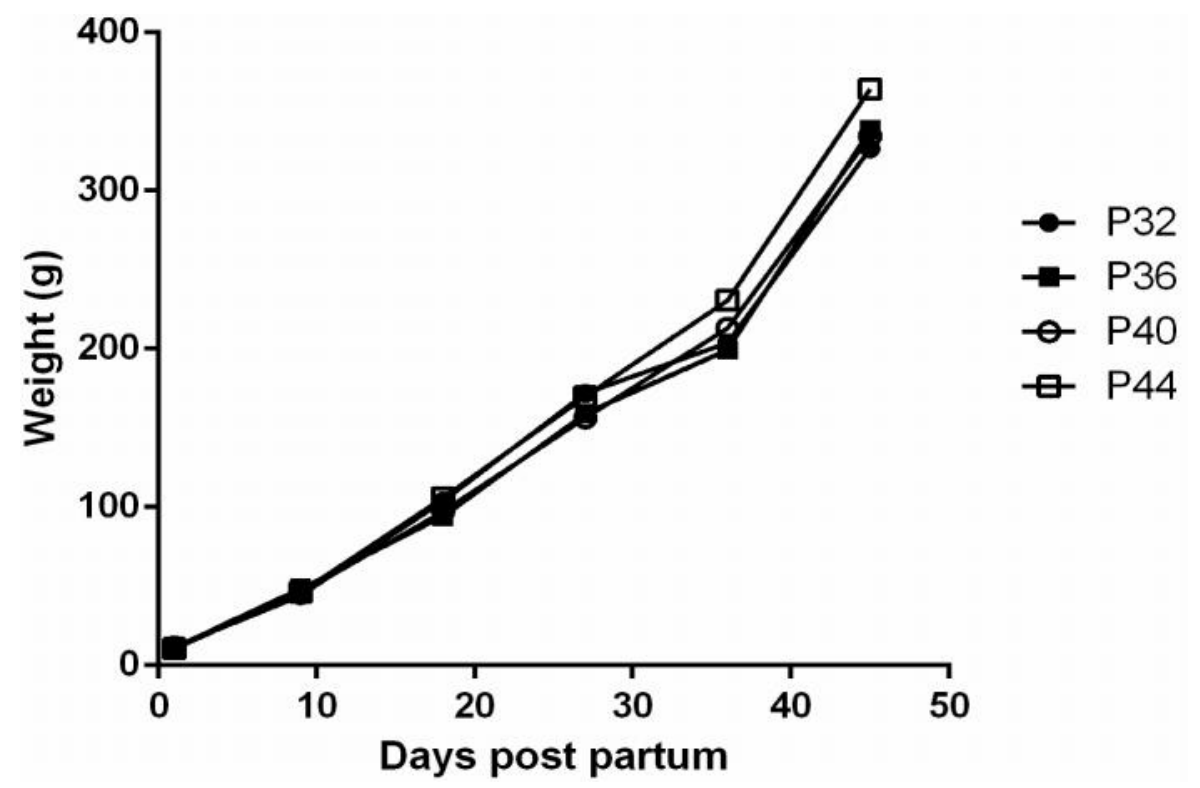

Fig 1. Growth curve of individual kits form all groups in lactation period.

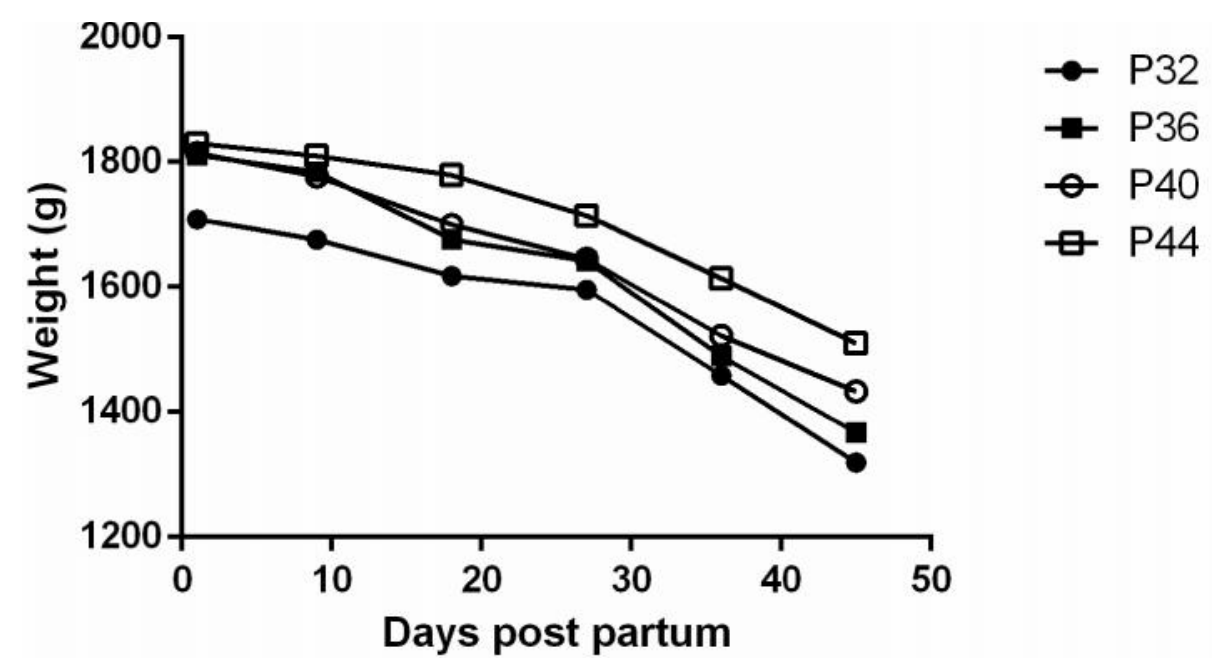

Fig 2. Live weight changes in mink dams of different groups during lactation period. 
Previous studies indicated that diet with adequate protein content significantly increased body weight of the kitten for up to 21 days of age (Matthiesen et al. 2010). In contrast, dams fed with inadequate protein supply were associated with increased loss of kits up to weaning (Vesterdorf et al. 2012). It is well known that for the first 24 to 25 days of life after birth, mink kits are totally dependent on mothers' milk for nourishment as they are born immature (Wamberg and Tauson 1998). Thus, meeting nutrient requirement of mink dams for maintenance and milk production are keys to the healthy growth of kits and decreasing their mortality. Other factors affecting kit mortality and growth include genetic causes, environmental factors and litter size (RouvinenWatt 2003; Schou and Malmkvist 2017; Karimi et al. 2018). In the present study, despite the variations in litter size within groups (with $12 \%-20 \%$ mink carrying 8-9 kitten), no significance was observed among treatments. These results are in line with findings by Damgaard et al. (2000) showing that decreasing protein supply from $61 \%$ to $39 \%$ of ME had no negative affect on body weight of the kits. In contrast, inadequate voluntary protein intake of dams could lead to decreased daily milk production of dams in those groups (Fink et al. 2001) and higher mortality of kit. Therefore, our study implies that adequate protein supply servers as an important factor for kitten survival in mink females with both average and high litter size during lactation.

Despite the lack of detailed knowledge of how body weight loss affects post-weaning performance of mink, available information from experimental studies on other animals, could be of referential values. For instance, it was reported in lactating sows that body weight loss and/or catabolic status may have detrimental effect on the interval period of weaning-to-service (Sterning et al. 1989; Zak et al. 1997; Zak et al. 1998), litter size (King and Williams 1984a; Kirkwood et al. 1987; Yang et al. 1989) as well as ovulation rate (Hughes and Pearce 1989; Zak et al. 1997). Moreover, body weight loss was found to be correlated negatively with the energy status in cows (Staples et al. 1990). In lactating mink, early research had shown that protein supply below the current recommendations increased dam weight loss (Fink et al. 2004). From parturition to 4 weeks postpartum, the loss of body weight (calculated in $\%$ of individual live weight), was lower in dams fed with medium protein $(45 \%$ of ME) and low protein ( $29 \%$ of ME) diets than in others fed with high protein $(63 \%$ of ME) (Fink et al. 2006). Similarly, our observations of reduced body weight loss in the group with $39 \%$ of ME were in agreement with previous findings in sows (King and Williams 1984b). Dietary requirement for nutrient standard in lactating mink varies depending on multiple factors including feed composition, nursed kits' number and lactation length. Our study was conducted under nochoice conditions, and since the mink were able to balance the macronutrients intake to maintain a constant energy intake, it is possible that the dams, when fed on diets of a low proportion of protein, chose to avoid overconsuming carbohydrate and/or lipids to gain limiting protein, as demonstrated by Mayntz et al. (2009). Therefore, the unbalanced feed might have failed to meet nutrient requirements for milk production and maintenance (Tauson 1996), consequently leading to impaired kit growth and weight loss of the dams.

Body reserves and profile changes of protein metabolism are affected by nutrients levels. Liver, as the primary source of serum protein, is known for its vigorous protein metabolism. Hence, hepatic protein metabolic status could be reflected by the serum TP content as a result of dietary treatments. Meanwhile, serum concentration of BUN can be used as an indicator of amino acid utilization and metabolism, due to its nature as a main end product of protein metabolism. In the current study, significantly decreased TP and BUN were observed in group P32 and P36, suggesting lowprotein diets may induce metabolic disorders by affecting hepatic protein metabolism after lactation.

GPT is one of the enzymes mainly located in hepatic cells and plays a critical role in the intermediary metabolism of amino acids and glucose. It has been reported that nutrient composition of a diet could influence the outcome of liver enzymes (Ryan et al. 2007).Our study showed an increasing trend in GPT activity from groups $\mathrm{P} 32$ to $\mathrm{P} 44$ with increasing protein content, which is in line with the early observation by Muramatsu and Ashida (1962), who noted GPT activities increased linearly in rats fed with diets with increasing casein content $(10,25,40$ and $60 \%)$. This could be explained by the possibility that high protein diet could increase gluconeogenesis by enhancing activities of enzymes involved in glucagon secretion, as demonstrated in rats(Eisenstein and Strack 1971; Eisenstein et al. 1974). Numerous studies have linked dietary protein intake with glucose homeostasis. The branched-chain amino acids support metabolic processes by serving as precursors for glutamine and alanine generation (Wahren et al. 1974; Ruderman 1975) and by modulating insulinsignaling pathway(Patti et al. 1998; Xu et al. 1998; Anthony et al. 2001). Studies have shown that indicated amino acids are the primary carbon source in hepatic gluconeogenesis (Jungas et al. 1992).Meanwhile, hepatic endogenous glucose production is a critical factor in blood glucose maintenance (Pascual et al. 1997; Katz and Tayek 1998). Enhancement of blood glucose utilization is especially critical during body weight loss to maintain body mass(Ludwig 2000). Layman et al. (2003) outlined that diets containing elevated protein and decreased $\mathrm{CHO} /$ protein ratio helped stabilize blood glucose level during weight loss via amino acids-glucose metabolism interaction. Therefore, the low-protein diets in this study might have led to reduced blood glucose level in dams, 
resulting in more weight loss. Furthermore, the positively correlated GLU level and GPT activity also suggests that with increasing dietary protein, the nutrient metabolism could be regulated to promote gluconeogenesis and amino acid degradation, in order to provide energy and blood glucose for overall being of metabolism.

Conclusion: In summary, our study shows that dietary protein influences nursing performance of female mink by affecting both growth rate of the kits and body weight loss of the dams. Signs of metabolic disorder, as indicated by serum biochemical parameters, are found in dams fed with low-protein diets. Thus, dietary protein content appears to be of crucial importance as a nutritional metabolic factor in modulating the nursing performance of dams. Based on our findings in this study, higher protein level (39\% of ME) could be used as dietary guidance to achieve optimal performance for lactating dams.

Acknowledgements: This work was supported by Special Fund for Public Welfare Technology Research of Agricultural Industry under Grant 200903014; Supporting Plan for Scientific and Technological Research of Jilin Province under Grant 20090238; Highlevel Talents Introduction Project of Anhui Institute of Science and Technology (DKYJ201701). The authors also thank all the crew at the fur farming of the Institute of Wild Animals and Plants, Chinese Academy of Agricultural Sciences.

Conflict of interest statement: The authors have no financial conflicts of interest.

\section{REFERENCES}

Anthony, J.C., T.G. Anthony, S.R. Kimball and L.S. Jefferson (2001). Signaling pathways involved in translational control of protein synthesis in skeletal muscle by leucine. J Nutr. 131: 856S-860S.

Clausen, T., C. Olesen, O. Hansen and S. Wamberg (1992). Nursing sickness in lactating mink (Mustela vison). I. Epidemiological and pathological observations. Can J Vet Res. 56: 89.

Damgaard, B.M., C.F. Børsting and R. Fink (2000). Effects of dietary protein and carbohydrate supply on feed consumption, growth performance and blood parameters in mink dams during the nursing period. Scientifur. 24: $17-21$.

Eisenstein, A.B. and I. Strack (1971). Effect of High Protein Feeding on Gluconeogenesis in Rat Liver. Diabetes. 20: 577-585.
Eisenstein, A.B., I. Strack and A. Steiner (1974). Glucagon stimulation of hepatic gluconeogenesis in rats fed a high-protein, carbohydrate-free diet. Metabolism. 23: 1523.

Fink, R. and C.F. Børsting (2002). Quantitative Glucose Metabolism in Lactating Mink ( Mustela vison ) - Effects of Dietary Levels of Protein, Fat and Carbohydrates. Act Agric Scan A Anim Sci. 52: 34-42.

Fink, R., C.F. Borsting, B.M. Damgaard and A.K. Rosted (2002). Glucose metabolism and regulation in lactating mink (Mustela vison)--effects of low dietary protein supply. Archiv fur Tierernahrung. 56: 155166.

Fink, R., A.-H. Tauson, A. Chwalibog, N. Hansen, N.B. Kristensen and S. Wamberg (2004). Effects of substitution of dietary protein with carbohydrate on lactation performance in the mink (Mustela vison). J Anim Feed Sci. 13: 647-664.

Fink, R., A.H. Tauson, A. Chwalibog and N.E. Hansen (2006). A first estimate of the amino acid requirement for milk production of the high-producing female mink (Mustela vison). J Anim Physiol Anim Nutr (Berl). 90: 60-69.

Fink, R., A.H. Tauson, K.B. Hansen, S. Wamberg and N.B. Kristensen (2001). Energy intake and milk production in mink(MUSTELA vison)-effect of litter size. Archiv für Tierernaehrung. 55: 221-242.

Glem-Hansen, N. (1979). Protein requirement for mink in the lactation period: methods for evaluation of protein requirement during lactation. Acta Agric Scand. 29: 129-138.

Hammer, A.S., L. Andresen, B. Aalbaek, P. Damborg, V. Weiss, M.L. Christiansen, S. Selsing and M.I. Bahl (2017). Abortion and mortality in farm mink (Neovison vison) associated with feed-born Clostridium limosum. Veterinary microbiology. 203: 229-233.

Hughes, P. and G. Pearce (1989). The endocrine basis of nutrition reproduction interactions. Manipulating Pig Production II: 290-295.

Hynes, A.M. and K. Rouvinen-Watt (2007). Monitoring blood glucose levels in female mink during the reproductive cycle: 1 . Prevention of hyperglycemia during the 
nursing period. Canadian J. Vet. Res. = Revue canadienne de recherche veterinaire. 71: 241-248.

Jiang, Q., G. Li, T. Zhang, H. Zhang, X. Gao, X. Xing, J. Zhao and F. Yang (2015). Effects of dietary protein level on nutrients digestibility and reproductive performance of female mink (Neovison vison) during gestation. Animal Nutrition. 1: 65-69.

Jungas, R.L., M.L. Halperin and J.T. Brosnan (1992). Quantitative analysis of amino acid oxidation and related gluconeogenesis in humans. Physiol Rev. 72: 419-448.

Karimi, K., M. Sargolzaei, G.S. Plastow, Z. Wang and Y. Miar (2018). Genetic and phenotypic parameters for litter size, survival rate, gestation length, and litter weight traits in American mink. J Anim Sci. 96: 25962606.

Katz, J. and J.A. Tayek (1998). Gluconeogenesis and the Cori cycle in 12-, 20-, and 40-hfasted humans. Am J Physiol Endocrinol Metab. 275: E537-E542.

Kiik, K., T. Maran, K. Nemvalts, S.L. Sandre and T. Tammaru (2017). Reproductive parameters of critically endangered European mink (Mustela lutreola) in captivity. Animal reproduction science. 181: 86-92.

King, R. and I. Williams (1984a). The effect of nutrition on the reproductive performance of first-litter sows 1. Feeding level during lactation, and between weaning and mating. Anim Prod. 38: 241-247.

King, R.H. and I.H. Williams (1984b). The effect of nutrition on the reproductive performance of first-litter sows 2. Protein and energy intakes during lactation. Anim Sci. 38: 249256.

Kirkwood, R., S. Baidoo, F. Aherne and A. Sather (1987). The influence of feeding level during lactation on the occurrence and endocrinology of the postweaning estrus in sows. Can J Ani Sci. 67: 405-415.

Korhonen, H. and P. Niemelä (1998). Effect of ad libitum and restrictive feeding on seasonal weight changes in captive minks (Mustela vison). J Anim Physiol Anim Nutr. 79: 269-280.

Korhonen, H.T., L. Jauhiainen, Rekil and T. auml (2002). Effect of temperament and behavioural reactions to the presence of a human during the pre-mating period on reproductive performance in farmed mink (Mustela vison). Can J Ani Sci. 82: 275282.

Layman, D.K., H. Shiue, C. Sather, D.J. Erickson and J. Baum (2003). Increased dietary protein modifies glucose and insulin homeostasis in adult women during weight loss. J Nutr. 133: 405-410.

Ludwig, D.S. (2000). Dietary glycemic index and obesity. J Nutr. 130: 280S-283S.

Ma, X., Y. Lin, Z. Jiang, C. Zheng, G. Zhou, D. Yu, T. Cao, J. Wang and F. Chen (2010). Dietary arginine supplementation enhances antioxidative capacity and improves meat quality of finishing pigs. Amino acids. 38: 95-102.

Matthiesen, C.F., D. Blache, P.D. Thomsen, N.E. Hansen and A.-H. Tauson (2010). Effect of late gestation low protein supply to mink (Mustela vison) dams on reproductive performance and metabolism of dam and offspring. Arch Anim Nutr. 64: 56-76.

Matthiesen, C.F., D. Blache, P.D. Thomsen and A.H. Tauson (2012). Foetal life protein restriction in male mink (Neovison vison) kits lowers post-weaning protein oxidation and the relative abundance of hepatic fructose-1,6-bisphosphatase mRNA. Animal. 6: 50-60.

Matthiesen, C.F., M.A. Casanas and A.H. Tauson (2014). Foetal life protein provision of mink (Neovison vison) changes the relative mRNA abundance of some hepatic enzymes regulating fat metabolism. Arch. Anim. Nutr. 68: 159-169.

Mayntz, D., V.H. Nielsen, A. Sørensen, S. Toft, D. Raubenheimer, C. Hejlesen and S.J. Simpson (2009). Balancing of protein and lipid intake by a mammalian carnivore, the mink, Mustela vison. Anim Behav. 77: 349-355.

Mcmillen, I.C. and J.S. Robinson (2005). Developmental origins of the metabolic syndrome: prediction, plasticity, and programming. Physiol Rev. 85: 571-633.

Muramatsu, K. and K. Ashida (1962). Effect of dietary protein level on growth and liver enzyme activities of rats. J Nutr. 76: 143150 . 
NRC (1982). Nutrient Requirements of Mink and Foxes,: Second Revised Edition, 1982. The National Academies Press, Washington, DC.

Ogden, B.E., W. Pang William, T. Agui and B.H. Lee (2016). Laboratory Animal Laws, Regulations, Guidelines and Standards in China Mainland, Japan, and Korea. ILAR J. 57: 301-311.

Pascual, M., F. Jahoor and P.J. Reeds (1997). Dietary glucose is extensively recycled in the splanchnic bed of fed adult mice. J Nutr. 127: 1480-1488.

Patti, M.E., E. Brambilla, L. Luzi, E.J. Landaker and C.R. Kahn (1998). Bidirectional modulation of insulin action by amino acids. J Clin Invest. 101: 1519-1529.

Rouvinen-Watt, K. (2003). Nursing sickness in the mink--a metabolic mystery or a familiar foe? Can J Vet Res. 67: 161-168.

Ruderman, N.B. (1975). Muscle amino acid metabolism and gluconeogenesis. Annu Rev Med. 26: 245-258.

Ryan, M.C., F. Abbasi, C. Lamendola, S. Carter and T.L. McLaughlin (2007). Serum alanine aminotransferase levels decrease further with carbohydrate than fat restriction in insulin-resistant adults. Diabetes Care. 30: 1075-1080.

Schou, T.M. and J. Malmkvist (2017). Early kit mortality and growth in farmed mink are affected by litter size rather than nest climate. Animal : an International J. Animal Bioscience. 11: 1581-1589.

Shaw, M.A., K.M. Rasmussen and T.R. Myers (1997). Consumption of a high fat diet impairs reproductive performance in Sprague-Dawley rats. J Nutr. 127: 64-69.

Skrede, A. (1978). Utilization of Fish and Animal Byproducts in Mink Nutrition: II. Effect of Source and Level of Protein on Female Reproductive Performance, and Preweaning Growth and Mortality of the Progeny. Acta Agric Scand. 28: 130-140.

Staples, C.R., W.W. Thatcher and J.H. Clark (1990). Relationship Between Ovarian Activity and Energy Status During the Early Postpartum Period of High Producing Dairy Cows 1,2. J Dairy Sci. 73: 938-947.

Sterning, M., L. Rydhmer, L. Eliasson, S. Einarsson and K. Anderson (1989). A study on primiparous sows of the ability to show standing oestrus and to ovulate after weaning. Influences of loss of body weight and backfat during lactation and of litter size, litter weight gain and season. Acta Vet Scan. 31: 227-236.

Tauson, A.-H. and E. Aldén (1984). Pre-mating body weight changes and reproductive performance in female mink. Acta Agric Scand. 34: 177-187.

Tauson, A. (1996). Prolactin profiles of pregnant, lactating and non-mated female mink (Mustela vison). J Reprod Fertil Suppl. 51: 195-201.

Vesterdorf, K., A. Harrison, C.F. Matthiesen and A.-H. Tauson (2012). Effects of protein restriction in utero on the metabolism of mink dams (Neovison vison) and on mink kit survival as well as on postnatal growth. Open J Anim Sci. 02: 19-31.

Wahren, J., P. Felig, G. Ahlborg, R. Hendler and L. Hagenfeldt (1974). Substrate turnover during prolonged exercise in man. J. Clin. Invest. 53: 1080-1090.

Wamberg, S. and A.H. Tauson (1998). Daily milk intake and body water turnover in suckling mink (Mustela vison) kits. Comp Biochem Physiol A Mol Integr Physiol. 119: 931939.

Xu, G., G. Kwon, C.A. Marshall, T.-A. Lin, J.C. Lawrence and M.L. McDaniel (1998). Branched-chain Amino Acids Are Essential in the Regulation of PHAS-I and p70 S6 Kinase by Pancreatic $\beta$-Cells: A possible role in protein translation and mitogenic signaling. J Biol Chem. 273: 28178-28184.

Yang, H., P. Eastham, P. Phillips and C. Whittemore (1989). Reproductive performance, body weight and body condition of breeding sows with differing body fatness at parturition, differing nutrition during lactation, and differing litter size. Anim Prod. 48: 181-201.

Zak, L., J. Cosgrove, F. Aherne and G. Foxcroft (1997). Pattern of feed intake and associated metabolic and endocrine changes differentially affect postweaning fertility in primiparous lactating sows. J Anim Sci. 75: 208-216.

Zak, L., I. Williams, G. Foxcroft, J. Pluske, A. Cegielski, E. Clowes and F. Aherne (1998). 
Feeding lactating primiparous sows to establish three divergent metabolic states: I. Associated endocrine changes and postweaning reproductive performance. $\mathrm{J}$ Anim Sci. 76: 1145-1153.

Zhang, H.H., G.Y. Li, E.J. Ren, X.M. Xing, Q. Wu and F.H. Yang (2012). Effects of diets with different protein and DL-methionine levels on the growth performance and $\mathrm{N}$-balance of growing minks. J. Anim. Physiol. Anim. Nutr. (Berl.). 96: 436-441.

Zhang, T.T., Z.Q. Zhang, X.H. Gao, F.H. Yang and X.M. Xing (2013). Effects of dietary protein levels on digestibility of nutrients and growth rate in young female mink (Mustela vison). J. Anim. Physiol. Anim. Nutr. (Berl.). 97: 271-277. 